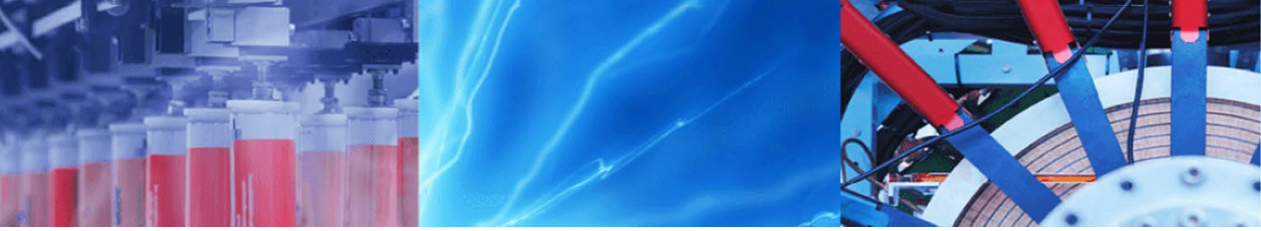

Research Article

\title{
Possibilities and Prospects Regarding Ethanol Production from Saccharin Sorghum [Sorghum bicolor (L.) Moench]
}

\author{
Anne Alves Macedo ${ }^{1}$ Raizza Gomes Medeiros ${ }^{1} \cdot$ Tatiane Aparecida Barroso Silvério $^{1}$. David Lee Nelson ${ }^{1}$. \\ Daniela Cristina Souza Oliveira ${ }^{1} \cdot$ Arlete Barbosa dos Reis ${ }^{1}$ (D)
}

Received: 24 March 2020 / Accepted: 18 November 2020 / Published online: 13 December 2020

(c) Springer Nature Switzerland AG 2020

\begin{abstract}
Sugarcane has been used as the principal raw material for ethanol production in Brazil, and its adaptability to the country's soil and climate represents an advantage. However, because of the high demand for fuel, coupled with the low production of off-season ethanol from sugarcane, it is necessary to search for other raw materials, such as sorghum [Sorghum bicolor (L.) Moench]. In addition to possessing characteristics similar to those of sugarcane, it can be cultivated in the off-season, thereby ensuring ethanol production throughout the year. This production would boost the regional economy, which is based on ethanol production from sugarcane. The present study proposes the establishment of an industry for the production of ethanol from saccharin sorghum to be implemented in the region of Ribeirão Preto, SP, Brazil. The estimated production of the industry proposed is 500,000 tons of saccharin sorghum per crop. Considering the consumption of approximately 202.25 tons/ $\mathrm{h}$, the production of 20 million liters of ethanol could be obtained at the end of the harvest. The company will have a staff of 300 employees, and the implementation at the productive, commercial, safety and environmental levels has been planned in accordance with the appropriate regulations related to the type of industry proposed.
\end{abstract}

Keywords Biofuels · Alternative source $\cdot$ Ethanol $\cdot$ Saccharin sorghum

\section{Introduction}

Following the oil crises, there has been a worldwide movement towards the development of new energy sources [1]. This movement has resulted in a growing demand for energy and liquid fuel [2]. As a result of the national alcohol program (pro-alcohol) in the 1970s, the country developed technologies for its production, and, according to [3], Brazil and the United States of America are the principal producers of first-generation ethanol. An alternative to conventional fuels is necessary, and ethanol as a good alternative [2].

Ethanol can be considered to be an alternative to alleviate environmental and energy problems worldwide resulting from lack of resources, rising fossil fuel prices and degradation caused by pollution [4]. In view of the economic advantage, recognized by the environmental gain of ethanol for the country, by emitting less carbon into the atmosphere compared to gasoline and other fuels $[5,6]$. In the 1980s, ethanol was the most commonly used fuel in passenger cars, although the level of ethanol use fell below that of gasoline due to the lack of ethanol in 1989 and the fall in international oil prices [7]. The decline in oil prices after 1985 led to a reversal of the diffusion of fuel ethanol. Sales of ethanol-powered vehicles plummeted to $1 \%$ in the late 1990s, and the overvaluation of the Brazilian currency (1994-1999) lead to an increase in ethanol production [7].

Arlete Barbosa dos Reis, arlete.reis@ict.ufvjm.edu.br | 'Department of Chemical Engineering, ICT-Institute of Science and Technology, UFVJM-Federal University of Jequitinhonha and Mucuri Valleys, JK Campus, Diamantina, Minas Gerais, Brazil. 
The growing international concern with the environmental issue is manifested in the expansion of national policies aimed at encouraging the production and consumption of biofuels. In this context, Brazil has a prominent role and the Brazilian sugar and alcohol sector, responsible for the production of fuel ethanol, has relevance. Since the early days of 2000s, the sector went through an expressive cycle of technological development and increased production, fueled by the growth in world demand for alternatives to fossil fuels [8]. Between 2000 and 2009, the share of ethanol in total fuel consumption by light vehicles increased from $16.9 \%$ to $39.3 \%$ [9]. Between 2000 and 2015 , the volume traded grew $288 \%$, increasing from 4.6 million $\mathrm{m}^{3}$ to 17.9 million $\mathrm{m}^{3}$. This is mainly due to the advent of flex fuel vehicles, starting in 2003, and to the tax policies that benefited the fuel derived from sugarcane [9]. Alston et al. [10] state that the virtuous evolution of Brazilian agriculture in the last 15 years cannot be traced back to specific policies, which could be replicated elsewhere, but rather to the more general institutional environment that has emerged since the mid-1990s, creating circumstances in which the government simultaneously reduced its interference in agriculture and provided the backdrop for the rule of law and greater predictability, where the private sector felt safe and able to invest and produce. However, admittedly, the country has advantages with regard to ethanol production because of advanced production technology. Its pursuit of leadership in the biofuel and energy agriculture market, [11]. However, the country is facing a time when it is necessary to increase ethanol production to meet internal and external demands [12]. This fact, due to the intensive expansion of the sugarcane activity, has occurred predominantly through the incorporation of areas and very little productivity gains. According to Demattê [13], Demattê et al. [14], and Nyko et al. [15], the conjunctural (short term) and structural (long term) factors are responsible for the downward trend in productivity of this activity in Brazil. Furthermore, when comparing the historical performance of the sugarcane harvest with other important Brazilian agricultural crops, such as corn and soybeans, from 1990 to 2014 [16], it is observed that, in addition to presenting much lower productivity gains, the agricultural performance of sugarcane has shown a downward trend in recent years. According to Bernardo et al. [17], studies carried out through qualitative and quantitative analyzes, it is possible to confirm the premises initially raised regarding the relevance of structural factors for the (non) evolution of sugarcane productivity in Brazil and in the regions of new expansions agricultural.

Thus, while the world was going through a long period of rapid growth in commodity prices, culminating in two episodes of food price crises in 2007-2008 and 2010-2011, interest increased in understanding how
Brazil achieved this transformation on farming activities. Increased production, as Brazil has done, mainly through greater total factor productivity, rather than the incorporation of new land and more labor, seems to be exactly what is needed to feed a growing and more global population prosperous, with its greater demand for food, fuel and meat, under the increasingly restrictive perspectives of a crowded world and climate change [18]. The negative effects of climate change on sugarcane production are very likely to worsen after 2050, especially if greenhouse gas emissions still remain high. Therefore, agricultural scientists and decision makers need to work closely to mitigate the potential negative effects of climate change on agriculture and to improve sugarcane yields by multidisciplinary approaches, such as consistently developing new sugarcane cultivars using breeding and molecular biology, refining best management practices, improving new technology transfer, and increasing productivity and profitability. Improving the resilience of sugarcane production systems to climate change requires protection of the natural resource (especially water and soil) for sustainability. Expanding use of sugarcane products for sugar, ethanol, cellulosic biofuel, and other coproducts can further improve profits [19]. On the other hand, there is a very important additional effect from the point of view of public health, based on the fact that ethanol is responsible for only $11 \%$ of the $\mathrm{CO}_{2}$ emitted by gasoline, which brings a significant improvement in the atmosphere breathed in large urban centers. This caused the city of São Paulo (Brazil), for example, to reduce air pollution and lung diseases [5, 6]. Several studies claim that Brazil can produce a diversity of plant products with bioenergetic potential because it is a country of great territorial extension, with fertile soils and an availability of water [20-23].

The use of new forms of energy that meet environmental and economic requirements are essential for ensuring sustainable energy development. Thus, it is necessary to develop studies with alternative crops that can supply the industrial sector with adequate amounts of raw materials, including extending the industrial processing period, with costs and efficiencies compatible with the market [24]. Several alternative raw materials have been studied and shown to be efficient in alcohol production, such as sugar-based materials (e.g., cane syrups, beet molasses), starch-based materials (e.g., cassava, corn, potatoes), and lignocellulosic materials (e.g., rice straw; sugarcane bagasse; corn stalks; grasses; pineapple stems, leaves and husks), in addition to sugar cane, cassava, and sorghum [25]. Sorghum offers tremendous potential as a raw material for the production of fuels and chemicals from cell wall sugars and biopolymers, whereas its structural and compositional heterogeneity within the plant may allow 
physical fractions to adapt the properties of the raw material to a biorefining process [26].

Saccharin sorghum is an optional raw material for the production of alcohol in the off-season for sugarcane, without having to make major adaptations in the equipment. The use of the same machinery present in the refinery is viable [27]. It is part of the Poaceas family, and it can be divided into five different types: grain, forage, saccharin, ligno-cellulosic and broom. The grain sorghum is the most widely cultivated type in the world. However, saccharin sorghum has been highlighted as a viable option in ethanol production [28]. Its sugars are water-extractable, representing a huge potential carbon source compatible with bioprocessing for use in a biorefinery. Using sorghum as a raw material, hybrid processes can be imagined employing cellulosic ethanol technologies coupled with first generation biofuel technologies, such as countercurrent extraction of water-soluble sugars [29]. This crop has a succulent stalk and sugarcane-like juice. It has fermentable sugars, and it can be used for the production of ethanol in the off-season for sugarcane using the existing facilities in sugarcane refineries, thus ensuring ethanol production for an entire year. These characteristics place saccharin sorghum on the level of a crop that is complementary to sugarcane and make it a raw material of increasing potential in Brazil [30]. Therefore, the development of a sorghum culture is fundamental for increasing ethanol production [27]. Within this context, the present work sought to develop, theoretically, the sizing of an ethanol production industry to be implanted in the city of Ribeirão Preto, São Paulo, Brazil, using sorghum [Sorghum bicolor (L.) Moench] as a raw material.

\subsection{Bibliographic review}

Saccharin sorghum is a summer crop (sugarcane offseason) with high levels of directly fermentable sugar in the stem. It is also characterized by being tolerant to abiotic stresses, which favors its development under different edaphoclimatic conditions and makes it a promising source of raw material for ethanol production. Also, it is noteworthy that both the harvesting and processing processes are the same as those adopted for sugarcane, and no adaptive changes are necessary. Saccharin sorghum can be cultivated in a sugarcane reformed area, [31-33]. Sorghum is drought tolerant and requires less fertilizer than corn. As a C4 photosynthesis plant, it is a highly efficient in the use of solar radiation and heat, so it manages water much more efficiently than corn. These properties and the occurrence of rainless periods lead many farmers to grow this crop under dry conditions rather than maize. Sorghum is also characterized by high starch $(64.3-73.8 \%$, dry basis) and protein (8.19-14.02\%, dry basis) contents $[34,35]$.

Among the agro-industrial raw materials, sorghum is one of the most versatile and efficient, both in photosynthetic capacity and maturation speed. According to Bandeira et al. [28], its multifunctional characteristics include the use of its grains as human and animal food, the use of the sugary juice present in its stalk for the production of anhydrous alcohol and alcoholic beverages, and the use of their panicles for broom production. In addition, its forage is used to feed ruminants. Originating in Africa (Ethiopia and Sudan), this plant has become one of the main crops on the world agricultural scene. It is the fifth most widely planted cereal in the world, second only to wheat, rice, corn and barley [36]. According to Cunha and Severo Filho [37], the use of saccharin sorghum to obtain ethanol adds benefits for producers, the industry and the economy of the country. Studies indicate that it can assume a leading role as a raw material for ethanol production, and further studies are needed on production policies and tax incentives.

According to Dar et al. [38], the renewable energy policy of different countries needs to be reevaluated and revisited according to energy demand and supply. Farmers or producers should be encouraged by providing adequate subsidies for the cultivation of sorghum. In addition, industrialists must be taken into account when framing the policies and tax regimes that are viable and favorable for the biofuels industry. All of this can contribute collectively to make saccharin sorghum a promising crop as a bioenergy resource.

Zhang et al. [39] concluded that total ethanol production includes both first- and second-generation ethanol production, emphasizing the possibility that a yield of $67.75 \mathrm{~g}$ of ethanol was obtained from $1 \mathrm{~kg}$ of fresh sweet sorghum stalk. Another possibility would be the co-fermentation of saccharin sorghum juice from acidpretreated bagasse for ethanol production through the biphasic fermentation process, which has already been successfully performed. Karla [40] states that the production and combustion of saccharin sorghum biofuels results in a reduction of almost $50 \%$ in the global warming potential ( $\mathrm{kg} \mathrm{CO}_{2}$-equivalent) when compared to conventional fuels for the functional unit of the total kilometers traveled. In addition, reductions in fossil fuel exhaustion (54\%), eutrophication (62\%), carcinogenicity (34\%) and ecotoxicity (11\%) are observed. Another perspective, cited by Tang et al. [41], is that the dualcrop system based on sweet saccharin sorghum has furnished a higher yield of dry biomass, efficient energy production and higher potential bioethanol yield than the double cultivation maize-based system. The double cultivation system of medium-ripened sweet sorghum 
and winter wheat produced a remarkable yield, good energy production and a quality superior to others. Therefore, the medium-term double sorghum and double wheat cultivation system might be recommended for application to saline and alkaline lands in the northern plain of China. The possibilities of reusing ethanol production in the sugarcane off-season in Brazil, particularly in the areas suitable for planting sorghum, According to Landau and Schaffert [42], the states of São Paulo, Minas Gerais, Goias, Paraná and Mato Grosso do Sul have high aptitude for planting sweet sorghum in the off-season of sugarcaneare

The Cerradinho refinery, located in Catanduva (SP), is a pioneer in the production of ethanol from saccharin sorghum on an industrial scale. Initially, according to data for 2012, the company started producing around 1.4 million liters of ethanol from 1200 hectares planted with sorghum. The production is still being tested in 11 more of its plants, which together consist of around 3100 planted hectares. As a basis for our theoretical study, 500 tons of stalks per hectare will be used, estimating to obtain about 40-60 I of ethanol produced per ton of stalks, according to data from EMBRAPA [43]. According to Canavialis [44], a harvest period of 120 days and an industrial activity of 103 days will be considered due to the efficiency of time optimization in this period, producing $24 \mathrm{~h}$ a day.

From the above data, the annual forecast can be made. Considering a production of 500,000 tons of sugarcane sorghum stalks per crop and the production of $40 \mathrm{I}$ of ethanol per ton of stalks, the industrial plant can process approximately 4854 tons of sorghum per day $(500,000$ tc/103 days. The plant will process about 202.25 tons/h of stalks (4854 tc daily/24 h), and a total production of $20,000,000$ I of hydrous ethanol per crop $(500,000 \mathrm{tc} \times 40 \mathrm{~L} /$ tc) will be obtained at the end of the harvest period.

\section{Material and methods}

\subsection{Material}

For the accomplishment of this work, studies of the market viability and the productive, economic and commercial processes were used.

\subsection{Methods}

The present work consisted of performing theoretical analyses and calculations capable of predicting the production of ethanol from sorghum on the basis of literature data, as follows:

\subsubsection{Identification of fixed and variable operating costs}

The criteria considered for verifying the economic viability are the choice of raw materials, the production volume, the industrial yield and the manufacturing cost [45]. Attention should be paid to the determination of fixed and variable investments, as well as the use of cash flow, Initial investments, Revenues, Costs, Financial Indicators, Net Present Value (NPV), Internal Rate of Return (IRR), Payback Method, concluding with the sensitivity analysis.

\subsubsection{Sensitivity analysis}

Historically, expression of sweet sorghum juice for syrup was a community activity in which farmers brought stalks to an expression facility and provided the necessary work to express and cook the juice. The process of crushing and squeezing sweet sorghum juice is called expression [46]. Within this context, industrially, they use heat exchangers.

According to Carvalho [47], the sensitivity analysis seeks to identify the consequence of the variation of economic parameters that influence the enterprise. The analyses were performed on the basis of sorghum production on an industrial scale considering the whole process. Several problems that diminish productivity can occur in soil manipulation, planting, harvesting and throughout the process. All these problems must be considered in the sensitivity analysis [48].

According to Dar et al. [38], the yield of ethanol (1.26-1.80 tons acre $\left.{ }^{-1}\right)$ and net energy production in terms of hydrogen and methane $\left(223,928 \mathrm{MJ} \mathrm{ha}^{-1}\right)$ from sweet sorghum are significantly larger than that obtained from other raw materials. Therefore, the concept of a zero waste biorefinery is the need of the hour to reap the full potential of sweet sorghum. Meanwhile, advanced technologies for ethanol production, the use of genetic engineering or biotechnology in sorghum to create efficient cultivars and the development of efficient ethanol-tolerant yeast strains and bacteria will meet future bioenergy demands.

For the present work, the initial production of ethanol from the sorghum will be $86 \%$ of the maximum capacity, with an increase of $5 \%$ per year. Initially, investments will be made with large financial aid because of the size of the project. The market rates for this type of financing are $0.8-1.3 \%$ for the purpose of calculation.

\section{Results and discussion}

For this project, the applicability of the production of bioethanol from sweet sorghum took into account: (1) Good adaptation to varied climatic conditions; (1) Sale in the period in which the price of ethanol increases as 
a result of the decrease in production that would occur in the sugarcane off-season; (2) Use of bagasse as an energy source in industries; (3) The replacement of nonrenewable fossil fuels by a renewable energy source.

\subsection{Initial investments}

\subsubsection{Revenue}

According to the weekly summary in the period from July 10 to July 17, 2015 [49], the average price of ethanol was quoted at $\mathrm{R} \$ 1.2292 /$. By adopting this value for our calculations and assuming a production volume of 8598 I/h we have Eq. (1):

$\frac{R \$ 1,2292}{1 L} \times \frac{8598 L}{1 h} \times 24 h \times \frac{365 d}{y}=92,581,475.62 R \$ / y$

Considering ethanol as the main product, an annual revenue from ethanol sales of $R \$ 92,581,475.62$ can be assumed. Regarding the physical space for the construction of the plant, the average price in the region of Ribeirão Preto, SP, Brazil, was around $R \$ 32,000$ /hectare between 2008 and 2012, according to Chiara [50]. The land area is 2.3 hectares of built area, so the total value of the acquisition is $R \$ 73,600.00$. Tables 1 and 2 illustrate the amounts invested in each process and industrial step.

Table 1 Initial investments in ethanol production

\begin{tabular}{lll}
\hline Individual equipment & $\begin{array}{l}\text { Investment } \\
\text { (R\$ million) }\end{array}$ & $\begin{array}{l}\text { Partici- } \\
\text { pation } \\
(\%)\end{array}$ \\
\hline $\begin{array}{l}\text { Unloading, cleaning, preparation and } \\
\text { extraction }\end{array}$ & 17.4 & 16.9 \\
Juice treatment and wort preparation & 9.3 & 9.0 \\
Alcohol fermentation & 25.4 & 24.7 \\
Distillation, rectification, dehydration & 15.4 & 15.0 \\
Steam and electricity generation & 33.7 & 32.7 \\
Other utilities & 1.8 & 1.7 \\
Total & 103.0 & 100 \\
Buildings and land for the industrial site & 39.5 & \\
Others & 35.6 & \\
Fixed capital & 178.1 & \\
Working capital & 26.7 & \\
Total investment & 204.8 & \\
\hline
\end{tabular}

Source: Novacana [51]
Table 2 Annual cost of the production of ethanol

\begin{tabular}{lrc}
\hline Item & Cost (R\$ million) & $\begin{array}{l}\text { Partici- } \\
\text { pation } \\
(\%)\end{array}$ \\
\hline Fixed costs & 16.7 & 10.2 \\
Cost of saccharin sorghum & 116.1 & 71.2 \\
Other raw materia & 2.0 & 1.2 \\
Equipament & 21.1 & 12.9 \\
Construction & 7.3 & 4.5 \\
Total & 63.2 & 100 \\
\hline
\end{tabular}

Source: Novacana [51]

\subsubsection{Costs}

\subsection{Economic indicators}

\subsubsection{Return on investment}

Considering the annual revenue of $\mathrm{R} \$ 92,581,475.62$, this consideration, based on theoretical data, as illustrated in items 3.1 and 3.1, a profit of 50 cents/I was estimated and, as a basis for our theoretical study, was the return on investment is calculated, thus obtaining an annual profit per harvest of $R \$ 46,290,737.81$, and the return will be the value of the profit divided by the investment, which is $\mathrm{R} \$ 204,800,000.00$, therefore the expected return will be obtained in approximately 4.4 years.

\subsection{Productive plan}

The proposed company seeks to produce 20 million liters of ethanol per crop of sweet sorghum, operating during the off-season for sugarcane. Thus, it will have a 24-h work regime, divided into three 8 -h shifts with $1 \mathrm{~h}$ of rest and meals within those $8 \mathrm{~h}$.

It will also have 300 employees, including director, administrative manager, sales manager, chemical engineers, occupational safety technicians, operators, farmers, secretaries, human resource employees, interns, janitors and drivers. These employees will work 8 hours a day, each one in his or her assigned shift, such as: Shift 1:07:00 to 15:00; Shift 2: 15:00 to 23:00; Shift 3: 23:00 to 07:00. The project will have a sustainable production chain with the plant producing the raw material and also producing the energy used.

\subsubsection{Description of the production process}

The steps that involve the production of ethanol using saccharin sorghum as a raw material constitute a process 
similar to that of ethanol from sugar cane, so that the same distillery structure and equipment of the process can be used as that of existing sugarcane to ethanol industries.

Therefore, in the present work, Fig. 1 illustrates a Process Block Diagram, where all the steps are detailed, focusing on the hydrous ethanol production process. Similarly, in order to add more information about the equipment used, presenting all process streams and their composition, Fig. 2 describes the Process Flow Diagram (PFD) of ethanol production in the sugar and alcohol industry.

\subsection{Commercial plan}

The project proposes the production of bioethanol from the sorghum juice. The industry will be implemented in the city of Ribeirão Preto. SP, Brazil. The soil is favorable for the planting of the raw material, there is a good availability of water in the region, and the location in relation to the main highways motivated this choice.

It will have a production capacity of 20 million liters of ethanol per crop. At first, the product will flow to Minas Gerais and to the consumer centers of the state of Sao Paulo, such as Paulinia and Sao Paulo. The product will be transported by trucks with a view to easy access to the highways that give access to these regions. All the raw materials used will be cultivated by the plant itself during the off-season for sugar cane.
Given that the economy of Ribeirão Preto and several nearby regions has a strong connection with ethanol production and that sugarcane is the main raw material, there is a considerable decline in the economy during the offseason. Therefore, the production of ethanol from saccharin sorghum in the sugar cane off-season will play a key role in the region's economy. Employment generation in the various sectors of the plant will provide working capital for a full year, boosting overall trade in the region.

\subsection{Energy balance}

Like the law of conservation of mass, the law of conservation of energy states that energy is not created, nor lost, but it can be stored or transferred to the environment where it is found in the form of work, heat or mass. The energy balance equation will consider the energy in the form of heat, and the energy contained in the molecules in the system and outside the system. Using Eq. (2) for the calculation of heat, the amount of heat a body receives or gives off when its temperature changes gives rise to a temperature gradient (dT) in Celsus. The specific heat $(\mathrm{Cp})$ is in $\mathrm{kcal} /\left(\mathrm{kg}^{\circ} \mathrm{C}\right)$, and the mass $(m)$ is in kilograms [52].

$$
Q=m \int C_{p} d T
$$

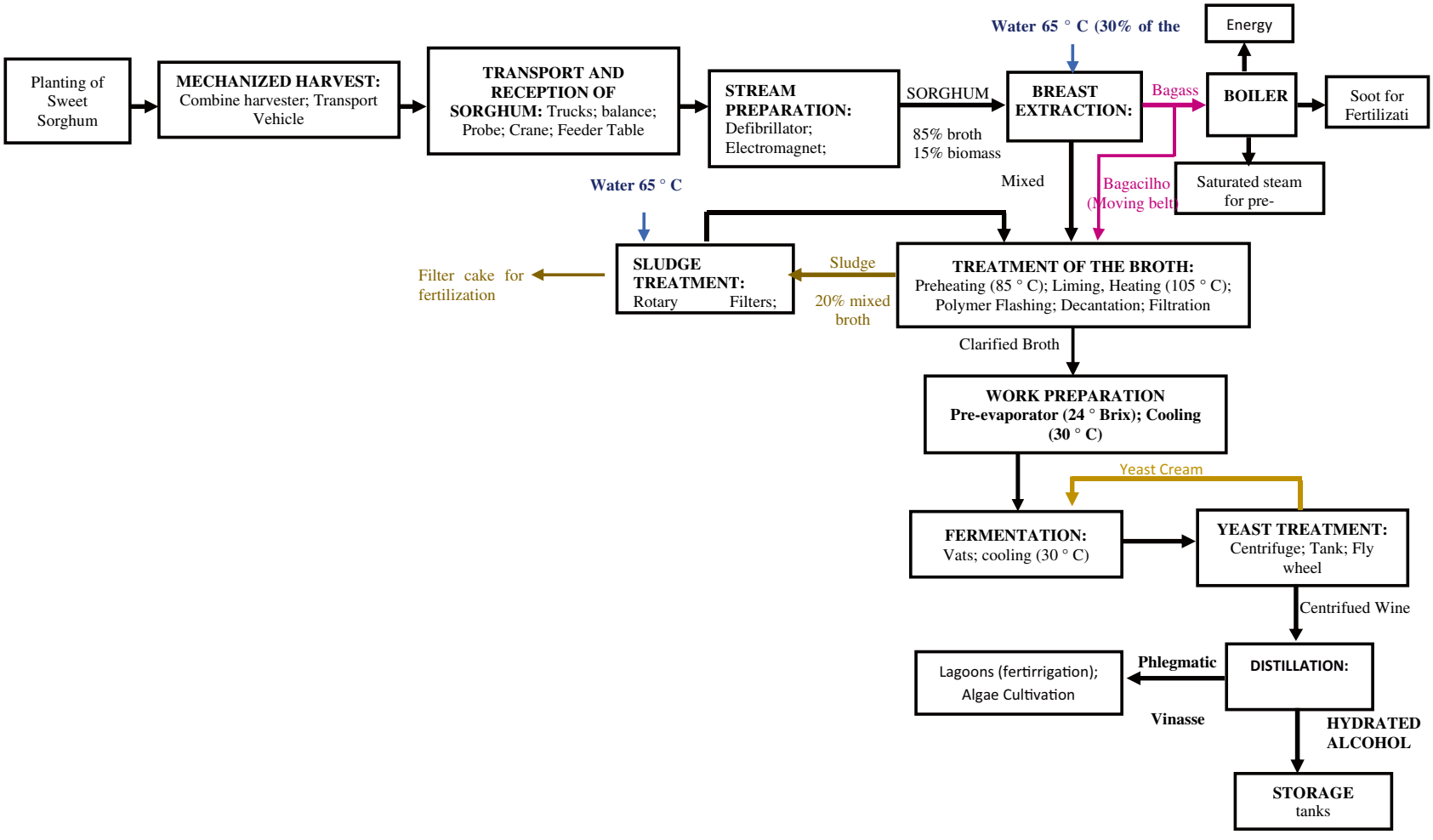

Fig. 1 Fluxogram of the process for producing etanol from saccharin sorghum [Sorghum bicolor (L.) Moench]. Source: authors 


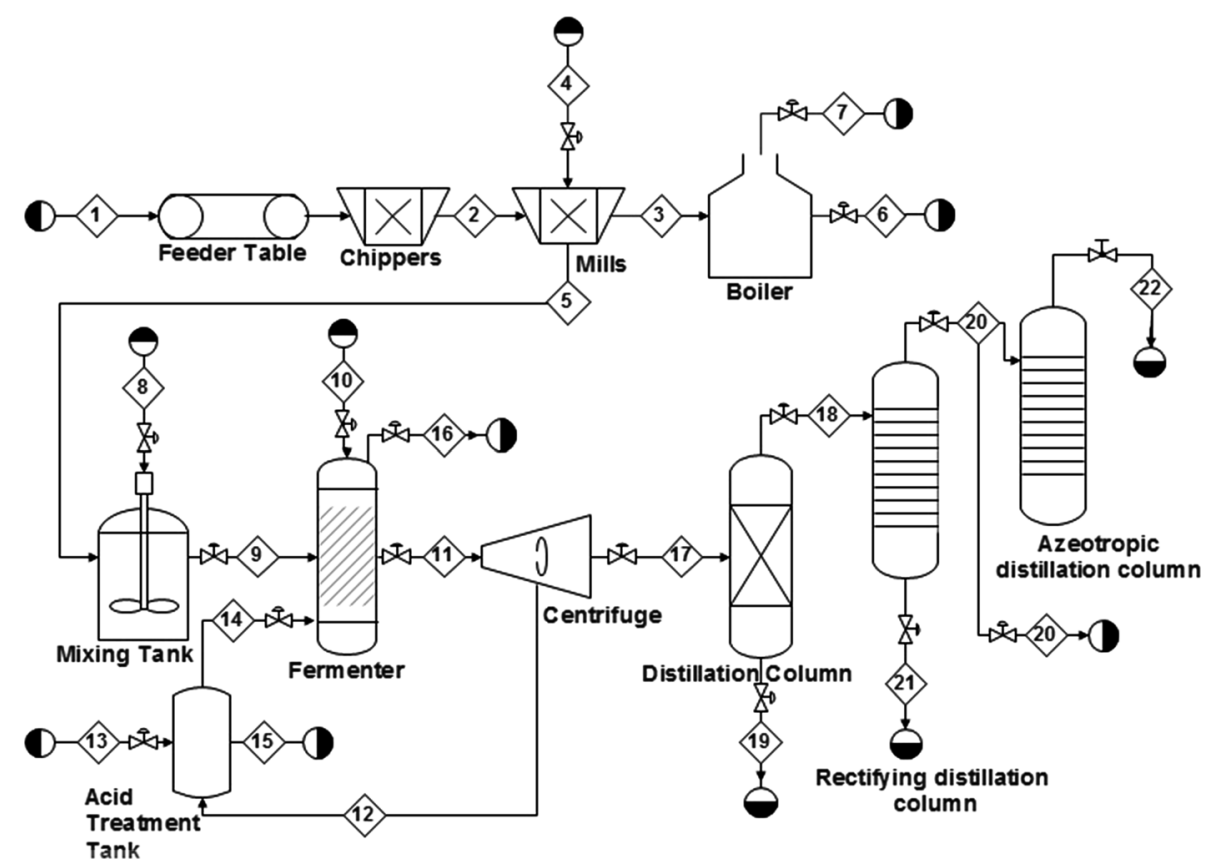

Fig. 2 Process flow diagram. Source: authors

According to Hugot [53], Eq. (3) is used to calculate the specific heat $(\mathrm{Cp})$ of the juice at the different concentrations of Brix during the process. Energy balance calculations also used process data from São Martinho [54]; the details of energy balance calculations are presented in Appendix II.

$C p=1-0,006 \times$ Brix

\subsubsection{Broth treatment}

The heat exchanger is used in the process step to preheat the mixed broth extracted in the milling step so as to utilize hot process fluids and save vapors and bagasse. When leaving the extraction step, the temperature of the mixed broth is $60^{\circ} \mathrm{C}$, and its temperature will be raised to $85^{\circ} \mathrm{C}$. The pre-evaporated clarified broth is used to heat the mixed broth; the heat to be supplied to the mixed broth stream ( $C_{-}$(4 Mixed Broth)) will be given by Eq. (4):

$Q_{\text {pre-heating }}=m_{4 \text { mixed broth }} \int_{60}^{85}$ mixed broth $=4,866,486.5 \frac{\mathrm{kcal}}{\mathrm{h}}$

The next heat exchanger used in this step of the process raises the temperature of the preheated mixed juice to $105^{\circ} \mathrm{C}$ with the objective of sterilizing the juice, facilitating the removal of gases during flashing, and decanting, coagulating and flocculating insoluble impurities present in the juice. The thermal exchange will occur with the live steam from the pre-evaporators, which has a temperature of $117^{\circ} \mathrm{C}$. It will be necessary to heat the broth ( $C_{-}$(4 Mixed Broth)) in accord with Eq. (5):

$\mathrm{Q}_{\text {heating }}=\mathrm{m}_{4 \text { mixed broth }} \int_{85}^{105} \mathrm{Cp}_{\text {mixed broth }}=3,893,189.2 \frac{\mathrm{kcal}}{\mathrm{h}}$

Thus, the energy balance established for this step in which the mixed broth is heated is given by Eq. (6):

$Q_{\text {Treatment of the broth }}=Q_{\text {pre-heating }}+Q_{\text {heating }}$

\subsubsection{Fermentation}

After decanting, the clarified broth ( $C_{-}$(8 Clarified Broth) $=173.37 \mathrm{tc} / \mathrm{h}$ ) at $95^{\circ} \mathrm{C}$ goes to the pre-evaporator where it is concentrated to $29.2 \%$ and reaches $24^{\circ}$ Brix at $115^{\circ} \mathrm{C}$. The broth is concentrated using direct steam coming from the boilers. Therefore, the energy balance established for the concentration of the clarified broth is given by Eqs. (7) and (8):

$$
\begin{aligned}
Q_{\text {Concentrate }} & =Q_{\text {sensitive water }}+Q_{\text {Latent water }}+Q_{\text {pre-evap. }} \\
Q_{\text {Concentrate }} & =252,850+27,333,085+3,113,725.2 \\
& =30,699,660.2 \frac{\mathrm{kcal}}{\mathrm{h}}
\end{aligned}
$$


The pre-evaporated broth is cooled by exchanging heat with the mixed broth. When leaving the evaporator at $115^{\circ} \mathrm{C}$, it gives off part of its energy, which is used to preheat the broth extracted from the mill and leaves at a lower temperature, calculated using Eqs. (9) and (10):

$Q_{\text {pre-heating }=-Q_{\text {cooling pre-evap. }}=4,866,48.5 \frac{\mathrm{kcal}}{\mathrm{h}}}$

$$
\begin{aligned}
-Q_{\text {cooling pre-evap. }}= & m_{\text {pre-evap broth. }} \int_{115}^{T_{\text {output }}} C p_{\text {pre-evap broth }} \\
& \rightarrow T_{\text {output }}=68.7^{\circ} \mathrm{C}
\end{aligned}
$$

Because it still has a high temperature, the pre-evaporated broth should be cooled again to $30^{\circ} \mathrm{C}$ using cold water to suit the conditions of the fermentation medium. In this step of must preparation, the yeasts become stressed if the must reaches the vat at a very high temperature, and the fermentation yield for ethanol production will be lower. Therefore, it is necessary to remove more energy from the must (Eq. (11)):

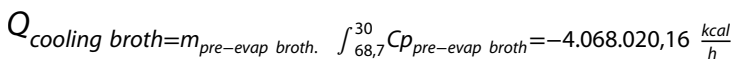

The sugar fermentation reaction (Eq. (12)) that occurs inside the vat is an exothermic process, where Eq. (13) represents the energy balance for the fermentation, and the heat released in the fermentation is furnished by Eq. (14) [50]:

$\mathrm{C}_{6} \mathrm{H}_{12} \mathrm{O}_{6} \rightarrow 2 \mathrm{C}_{2} \mathrm{H}_{5} \mathrm{OH}+2 \mathrm{CO}_{2}+\mathrm{HEAT}$

$3800 \frac{\mathrm{kcal}}{K g_{\text {sugar }}} 3534 \frac{\mathrm{kcal}}{K g_{\text {sugar }}}+174.8 \frac{\mathrm{kcal}}{K g_{\text {sugar }}}$

$Q_{\text {fermentation }=m_{A R T}} \times \mathrm{RF} \times \mathrm{CE} \times \mathrm{HEAT}=1,186,383.6 \frac{\mathrm{kcal}}{\mathrm{h}}$

Because of the release of heat and the need to maintain the fermentation temperature at $30^{\circ} \mathrm{C}$, a system is used to cool the raw wine inside the vat to maintain the ideal temperature for ethanol production and avoid the formation of byproducts whose removal would be necessary (Eq. (15)):

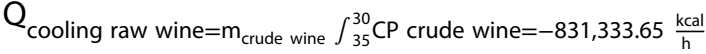

\subsubsection{Distillation}

The wine will be centrifuged at $30^{\circ} \mathrm{C}$ and distilled. It must be heated until $97 \%$ of the ethanol present in the stream is removed. The heat required in the distillation step can be calculated using Eqs. (16) and (17):

$$
\begin{aligned}
Q_{\text {Destill }} & =Q_{\text {Sensitive Ethanol }}+Q_{\text {Latent Ethanol }}+Q_{\text {centrifuged wine }} \\
Q_{\text {Destill }} & =299,271.6+2,155,770+8,917,418.55 \\
& =11,372,460.15 \frac{\mathrm{kcal}}{\mathrm{h}}
\end{aligned}
$$

\subsection{Economic feasibility}

The analysis of the economic viability of a project is extremely important because it is where it is possible to visualize the potential return and the existing risks. It is necessary when you want to create or expand a project. According to Mathur et al. [55], instead of competing with food crops for arable land, the cultivation of sweet sorghum will help a lot in the conservation of marginal lands, converting them to agricultural lands.

Agronomic production systems are evolving and are unique to specific production environments. In addition, the development of various ways of processing the production of sweet sorghum bioenergy has been explored. While it has been economically viable to produce sweet sorghum in certain geographic regions, other places have shown the opposite Appiah-Nkansah et al. [56]. According to the Bioenergia [57], the production of ethanol from sorghum in the off-season can yield a significant amount of ethanol for the sugar-energy industries, amounting to approximately 3500-5000 I/hectare/year, equivalent to 5 billion liters of biofuel in the current scenario in Brazil. Therefore, interest in the use of sorghum in industries is increasing. Mathur et al. [55], claim that sweet sorghum can play a significant role in addressing the growing need for renewable energy to replace fossil fuels with fuel-based energy resources.

Regarding the marketing aspects of ethanol, it is necessary to determine opportunities for the integration of sweet sorghum into cultivation systems without compromising the sustainability and interruption of agricultural production for other purposes, including food [46]. Although it is possible to highlight a positive scenario related to biofuels from geopolitical issue up to environmental issues [48]. Dar et al. [38] state that saccharin sorghum, with its high adaptability to drought, saline, alkaline and water register conditions, is the best choice for implementation under hot and dry climatic conditions. It is the best choice both for economic and environmental considerations because it is harvested three to four months after planting, and it is planted one to two times a year. The production of energy is greater than those obtained from sugar cane, sugar beets, corn, wheat, etc. The conflict that arises from the diversion of 
farmland to its cultivation for fuel is alleviated because sweet sorghum meets the diverse requirements of food, fuel and fodder. Therefore, such conflicts are offset.

To illustrate these trends and the resultant decrease in SOj emissions over the 21st century, emissions in the B2-MESSAGE scenario [58] are analyzed. Global energyrelated $\mathrm{SO}_{2}$ emissions $\mathrm{m}$ this $\mathrm{B} 2$ scenario decline from 59 MtS in 1990 to about $12 \mathrm{MtS}$ in 2100 . The primaiy causes for this reduction are the transition to more advanced coal technologies and desulfurization [59]. In the second half of the $21^{\text {st }}$ century, desulfurization of the energy system also takes place because of the production of methanol from coal. Sulfur removal is a process-inherent featare. Methanol is mainly used in the transport sector as a substitute for oil products that become scarce after 2050. Increased use of diesel engines can reduce $\mathrm{CO}_{2}$ emissions, but leads to greater emissions of other gaseous pollutants, such as $\mathrm{N}_{2} \mathrm{O}$ and carbon monoxide (CO). Use of alternative fuels, such as compressed natural gas, LPG, and ethanol, can significantly reduce $\mathrm{CO}_{2}$ emissions from transport [60]. Fernandes et al. [61], in their study, concluded that the sowing time of sweet sorghum, in the harvest period, resulted in higher yield of fresh stem material, fresh matter of total biomass, broth mass and Brix, independent of the plant arrangement, they also concluded that the spacing of $50 \mathrm{~cm}$ between rows resulted in greater production of total biomass and broth mass ha-1, regardless of sowing time. In contrast, it was found that the double spacing resulted in values similar to the $80 \mathrm{~cm}$ spacing for the main productive variables, regardless of the sowing time. Plant populations did not influence the fresh matter yield of stalks and broth mass, regardless of sowing time.

According to Briand et al. [62], the economic analysis of ethanol production from sweet sorghum in Mississippi [63] found no "incentive to produce sweet sorghum as a raw material". According to U.S. Department of Agriculture, the ratio of energy invested to energy obtained during biofuel extraction from sweet sorghum is estimated as $1: 8$, which may further be improved using engineering and molecular breeding technologies [64]. Although, the annual production of sweet sorghum ethanol depends on several factors, including genetic history, time of year, soil quality and other environmental issues factors, it is estimated that the sweet sorghum crop produces to $8000 \mathrm{~L} / \mathrm{h}$ /year of ethanol [46], Kim and Day [65], confirm that a consistent and reliable supply of raw materials throughout the year is a significant cost component for the production of bioethanol, including the feasibility of incorporating new crops in the existing sugarcane infrastructure and the possibility of partitioning the raw materials for fuel and sugar during the normal sugarcane processing season sugar in Louisiana.

Furthermore, it is correct to say that biomass is an important factor in mitigating climate change, as well as according to IPCC studies, fossil fuels must be replaced by new and renewable sources of energy. Thus, the IPCC reports present proposals that aim to contribute to mitigate the consequences of global warming, highlighting the incentive to use alternative energies, which do not involve the burning of fossil fuels, with the adoption of mechanisms that generate carbon credits. , as well as the taxation of carbon emissions in the energy sector [66]. In this area, the use of biomass as biofuel for energy generation is the main factor in achieving GHG emissions reductions and, the option of sweet sorghum as a raw material, represents only $53 \%$ reduction in substitution to fossil fuels $[67,68]$.

In this sense, some researchers continue to invest in research in order to achieve improvements in this regard. Ottman et al. [69], concluded that sorghum yields are probably higher than those present in areas where sorghum is grown with limited water. In high rain or irrigated areas, total sorghum production may not be affected by an increase in atmospheric $\mathrm{CO}_{2}$. Grossi et al. [70], in their study on the vulnerability of sorghum production for the current (1982-1999) and future (2047-2064) seasons, applying climatic observations and climatic results, concluded that with regard to future conditions, the simulations indicated that in Janaúba (Brazil) the average yields for current and future climatic conditions were not statistically different, but in Sete Lagoas (Brazil) there was a statistically significant increase in sorghum productivity. Kelland et al. [71], in their study on improved soil-based rock weathering (ERW) concluded that reactive geochemical transport modeling, limited by elementary budgets, indicated $\mathrm{CO}_{2}$ sequestration rates of 2-4 $\mathrm{tCO}_{2} / \mathrm{ha}, 1-5$ years after a single application of basaltic rock powder, it is known, however, that elementary budgets indicate substantial release of basic cations important for the removal of inorganic carbon and its accumulation mainly in exchangeable soil reservoirs.

However, the authors concluded that the competitiveness of sweet sorghum as an ethanol feedstock will change with increases in yields, reduction in transportation costs and increases in ethanol prices. Using the whole crop, Barcelos et al. [72] was able to obtain $160 \mathrm{~L}$ of ethanol per ton of sweet sorghum with $18 \%$ grain ethanol, $28 \%$ juice and $54 \%$ bagasse. This result translates to $13,600 \mathrm{~L}$ of ethanol/ha, the highest yield of any crop, including maize and sugarcane [73]. Appiah-Nkansah et al. [56], in their study, concluded that sweet sorghum contains fermentable sugars in the juice (53 and $85 \%$ sucrose, 9 and $33 \%$ glucose and 6 and $21 \%$ fructose) can be fermented directly in ethanol. The grain is mainly starch (62-75\%), which can be hydrolyzed and fermented in ethanol, bagasse, a fibrous lignocellulosic material, can be used to produce cellulosic ethanol, heat and / or cogeneration energy. In general, it is possible to 
infer that sorghum has a great potential as a raw material for ethanol production.

Barcelos et al. [74], in his study concluded an experimental protocol for finding the best conditions for granular starch enzymatic hydrolysis of sorghum grains at low enzyme loads was successfully developed, resulting in an overall conversion efficiency of $99.3 \%$. An ethanol concentration of $105.8 \mathrm{~g} \mathrm{~L}^{-1}$ was attained at $24 \mathrm{~h}$ of fermentation. This result is of considerable practical importance from the economic standpoint, since the production cost of ethanol is mainly derived from the raw material and energy costs. High ethanol yield $\left(0.499 \mathrm{~g} \mathrm{~g}^{-1}\right)$ and volumetric productivity $\left(4.41 \mathrm{~g} \mathrm{~L}^{-1} \mathrm{~h}^{-1}\right)$ were reached in fermentation, demonstrating that sorghum can be an alternative for Brazil and other countries, since it is a culture that adapts to different soil types and climate. According to research performed by the company, the machinery for the production of ethanol is the same as that used in the production from sugar cane and only minor adjustments are required [75]. Therefore, the insertion of saccharin sorghum in the sugar cane off-season will revolutionarily affect the scenario of Biofuel, assuming that it will supply demand in a period that is commonly declining in production. A production of $2500 \mathrm{l} / \mathrm{hectare} / \mathrm{year}$ can be obtained with a viable planting cost of $R \$ 2000 /$ hectare, compared to sugarcane which is $\mathrm{R} \$ 5000 /$ hectare, proves the advantage of the cultivation of sorghum as a complement for ethanol production in the factories [76].

Dar et al. [38], in their study, evaluated the direct conversion cellulose in ethanol by 16 natural bacterial pools collected from a variety of habitats in China and claim that the best consortium (HP consortium) produced an ethanol grade of $2.06 \mathrm{~g} / \mathrm{L}$ from $7 \mathrm{~g} / \mathrm{L}$ of a-cellulose or $1.65 \mathrm{~g} / \mathrm{L}$ ethanol grade of $7 \mathrm{~g} / \mathrm{L}$ of sweet sorghum stem after 6 days at $55^{\circ} \mathrm{C}$. When analyzing the structure of the consortia, they found that $P$. taiwanensis played an important role in the high ethanol productivity of the HP consortium. In parallel, Li et al. [26] affirm that Sweet Sorghum may produce grain, sugar, ethanol, electricity, and feed without adversely impacting existing food crops or requiring the clearing of new land to grow fuels crops. Grown in drier areas (waste lands or sandy soils) with only limited water and fertiliser as compared to sugar cane and other crops. Sweet Sorghum is significantly salt-tolerant, permitting it to be grown in high-salinity soils that are often unusable for other crops (e.g., in high salinity), it as high yield stalks: 70 ton/ha/harvest, 4 months per harvest and is possible producing additional food ( 3 ton/ha/harvest) without the necessity to displace existing crops, such ad corn.

In the present work, we have shown that sorghum has a visible and very important advantage based on its properties. There are its short cycle and its planting, which can be achieved with seeds and, thus, its management through mechanization. In addition, the stalks have considerable levels of sugars that can be fermented directly [77]. However, studies elucidating the mechanism behind the combined responses to stress, imitating the real life situation in the fields would be necessary to optimize the breeding programs and agronomic practices needed under different climatic conditions Mathur et al. [55]. As well as for a more accurate analysis requires appropriate tools for further studies, carried out from the cash flow using its revenues and costs.

\section{Conclusions}

The present work demonstrates that the actions and concerns with energy issues, taking the environmental and financial aspects into consideration, result in a constant search for new technologies, and a lower dependence on oil, aiming for a better performance of these new energy sources for each society that is increasingly demanding and needs sustainable fuel for progress. By carrying out the virtual implementation project for the industry aiming at the production of ethanol in the sugarcane off-season, we obtained a production of over 20 million liters of ethanol sold in the domestic market. This work describes the equipment and utilities necessary for the implementation and operation of the project for the production of ethanol from sorghum. The project is considered viable as long as ethanol from sorghum is used to supplement sugarcane ethanol production. The importance of using production residues to avoid environmental problems and convert them into new sources of business. Considering, above all, that the present work deals with a theoretical study on the implantation of a new ethanol industry from sweet sorghum.

Acknowledgements The authors thank the GEPAEQ-Group of Studies and Research Applied to Chemical Engineering/UFVJM.

Conflict of interest The author(s) declare that they have no competing interests.

\section{References}

1. Randow BMV, Fontes RMO, Mattos LBD, Filho EA (2013) Os determinantes da oferta e da demanda de etanol nos estados brasileiros. Rev Bras Energia 19:287-319

2. Mayer FD, Brondani M, Hoffmann R, Feris LA, Marcilio NR, Baldo $V$ (2016) Small-scale production of hydrous ethanol fuel: economic and environmental assessment. Biomass Bioenergy 93:168-179

3. Goldemberg J (2009) The Brazilian experience with biofuels (innovations case narrative). Innovations 4(4):91-107

4. Pacheco TF (2011). Produção de etanol: primeira ou segunda geração? Embrapa Agroenergia-Circular Técnica (INFOTECA-E) 
5. NOVACANA (2020) Agronegócio perde Diniz Junqueira, um dos 'pais' do Proálcool. https://www.novacana.com/n/indus tria/usinas/agronegocio-perde-diniz-junqueira-pais-proal cool-260220. Acessed in 28/04/2020

6. NOVACANA (2020) Carro movido a etanol: Um aniversário sustentável https://www.novacana.com/n/etanol/meio-ambie nte/carro-movido-etanol-aniversario-sustentavel-141019. Acessed 28/04/2020

7. Sorda G, Banse M, Kemfert C (2010) An overview of biofuel policies across the world. Energy Policy 38(11):6977-6988

8. Baran PH, Coelho LF (2015) Evolução Recente do Mercado de Etanol Hidratado - Cenários e Perspectivas. ANP: Nota Técnica Conjunta SPD/SAB n 01/2015. RJ-Brazil

9. ANP, A. N. D. P. Gás Natural e Biocombustíveis (2016) Panorama do abastecimento de combustíveis: 2016. [Livro eletrônico.]. ANP, Rio de Janeiro

10. Alston L, Melo M, Mueller B, Pereira C (2016) Brazil in transition: beliefs, leadership and institutional change. Princeton University Press, Princeton

11. EPE (2010) Balanço energético nacional: Ano base 2009. Brasília, EPE

12. Alvarez Gomez PA (2011) Simulação de diferentes alternativas de arranjo de uma unidade de fermentação piloto móvel para produção de etanol

13. Demattê JLI (2012) Variedades de cana estão devendo. Rev RPANEWS 11(141):16-24

14. Demattê JAM, Demattê JLI, Alves ER, Barbosa RN, Morelli JL (2014) Precision agriculture for sugarcane management: a strategy applied for Brazilian conditions. Acta Scientiarum. Agronomy 36(1):111-117. https://doi.org/10.4025/actasciagr on.v36i1.17664

15. Nyko D, Valente MS, Milanez AY, Tanaka AKR, Rodrigues AVP (2013) A evolução das tecnologias agrícolas do setor sucroenergético: estagnação passageira ou crise estrutural? BNDES Setor 37:399-442

16. Instituto Brasileiro de Geografia e Estatística - IBGE (2015) Tabela 1612. Rio de Janeiro. http://www.sidra.ibge.gov.br/bda/ tabela/listabl.asp?c=1612\&z=p\&o=24. Accessed September 2020

17. Bernardo R, Lourenzani WL, Satolo EG, Caldas MM (2019) Analysis of the agricultural productivity of the sugarcane crop in regions of new agricultural expansions of sugarcane. Gest Prod 26(3):19. https://doi.org/10.1590/0104-530×3554-19

18. Mueller B, Mueller C (2016) The political economy of the Brazilian model of agricultural development: institutions versus sectoral policy author. Q Rev Econ Finance 62:12-20. https://doi. org/10.1016/j.qref.2016.07.012

19. Zhao D, Li Y-R (2015) Climate change and sugarcane production: potential impact and mitigation strategies. Int J Agron 2015:1-10. https://doi.org/10.1155/2015/547386

20. Ferreira VF, Silva FDCD, Ferreira PG (2013) Carboidratos como fonte de compostos para a indústria de química fina. Quím Nova 36(10):1514-1519

21. Masiero G, Lopes H (2008) Ethanol and biofuels as alternatives energetic sources: Latin-American e Asian perspectives. Rev Bras Polít Int 51(2):60-79

22. Rezende ML, Richardson JW (2017) Risk analysis of using sweet sorghum for ethanol production in southeastern Brazil. Biomass Bioenergy 97:100-107

23. Santos MDSM, Cardoso CAL, Silva EM, Batistote M (2018) Potential of saccharine substrates for ethanol production. Orbital 10(1):14-21

24. May A, Durães FOM, Pereira Filho IA, Schaffert RE, da Costa Parrella RA (2012) Sistema Embrapa de produção agroindustrial de sorgo sacarino para bioetanol sistema BRS1G-tecnologia qualidade Embrapa. Sistema 1(3):9
25. Nuanpeng $S$, Thanonkeo S, Klanrit $P$, Thanonkeo $P$ (2018) Ethanol production from sweet sorghum by Saccharomyces cerevisiae DBKKUY-53 immobilized on alginate-loofah matrices. Braz J Microbiol 49:140-150

26. Li M, Yan G, Bhalla A, Maldonado-Pereira L, Russell PR, Ding S-Y et al (2018) Physical fractionation of sweet sorghum and forage/energy sorghum for optimal processing in a biorefinery. Ind Crop Prod 124:607-616

27. Albuquerque CJB, Tardin FD, Parrella RADC, Guimarães ADS, Oliveira RMD, Silva KMDJ (2012) Sorgo sacarino em diferentes arranjos de plantas e localidades de Minas Gerais. Rev Bras Milho Sorgo 11(1):69-85

28. Bandeira A, MÜller L, Medeiros S, Leal L, da Silva N, Emygdio B et al (2012) Parâmetros tecnológicos de sorgo sacarino BRS 506, cultivado em distintas épocas de semeaduras e espaçamento de entrelinhas. In Embrapa Clima Temperado-Artigo em anais de congresso (ALICE), 2012: In: Simpósio Estadual de Agroenergia, 4.; Reunião Técnica de Agroenergia, 4

29. Eggleston G, Cole M, Andrzejewski B (2013) New commercially viable processing technologies for the production of sugar feedstocks from sweet sorghum (Sorghum bicolor L. Moench) for manufacture of biofuels and bioproducts. Sugar Tech 15(3):232-249

30. Arruda R (2012) Sorgo sacarino: Origem, Finalidades e Vantagens -Rural Centro. http://ruralcentro.uol.com.br/noticias/sorgo -sacarino-origem-finalidades-e-vantagens-60576. Accessed 02 dez 2014

31. Almodares A, Hadi M (2009) Production of bioethanol from sweet sorghum: a review. Afr J Agric Res 4(9):772-780

32. Bernardes JVS, Júnior VO, Charlo HCO, Fernandes G, Bosco LPV (2019) Doses de potássio para o sorgo sacarino destinado à produção de etanol

33. Durães $F$ (2011) Sorgo sacarino: tecnologia agronômica e industrial para alimentos e energia. Embrapa Agroenergia-Outras publicações técnicas (INFOTECA-E)

34. Nghiem NP, Montanti J, Johnston DB (2016) Sorghum as a renewable feedstock for production of fuels and industrial chemicals. Bioengineering 3(1):75-91

35. Szambelan K, Nowak J, Szwengiel A, Jeleń H (2020) Comparison of sorghum and maize raw distillates: factors affecting ethanol efficiency and volatile by-product profile. J Cereal Sci 91:102863. https://doi.org/10.1016/j.jcs.2019.102863

36. May A, de Albuquerque Filho MR, Rodrigues JAS, Landau EC, Parrella RDC, Massafera R (2011) Cultivares de sorgo para o mercado brasileiro na safra 2011/2012. Embrapa Milho e SorgoDocumentos (INFOTECA-E)

37. Cunha SP, Severo Filho WA (2010) Avanços tecnológicos na obtenção de etanol a partir de sorgo sacarino (Sorghum bicolor (L.) Moench). Tecno-Lógica 14(2):69-75

38. Dar RA, Dar EA, Kaur A, Phutela UG (2018) Sweet sorghum-a promising alternative feedstock for biofuel production. Renew Sust Energ Rev 82:4070-4090

39. Zhang C, Wen H, Chen C, Cai D, Fu C, Li P et al (2019) Simultaneous saccharification and juice co-fermentation for high-titer ethanol production using sweet sorghum stalk. Renew Energy 134:44-53

40. Morrissey K (2017) Life cycle assessment of sweet sorghum as feedstock for second-generation biofuel production

41. Tang C-C, Yang X-L, Xie G-H (2018) Establishing sustainable sweet sorghum-based cropping systems for forage and bioenergy feedstock in North China Plain. Field Crop Res 227:144-154

42. Landau $\mathrm{E}$, Schaffert $\mathrm{R}$ (2011) Zoneamento de áreas aptas para o plantio de sorgo sacarino na época de entressafra de cana-deaçúcar no Brasil

43. Embrapa EMES (2012) Processamento Industrial do Sorgo Sacarino. http://ainfo.cnptia.embrapa.br/digital/bitstream/ 
item/68403/1/Processamento-agroindustrial.pdf. Accessed 28 Jan 2015

44. CANAVIALIS (2012) Produtividade do sorgo sacarino nas usinas aumentou em 55\% na safra de 2011/12. http://www. canavialis.com.br/artigos/produtividade-do-sorgo-sacarinonas-usinas-aumentou-em-55-na-safra-2011-12. Accessed 06 de mar 2015

45. Pimenta GG, Oliveira LRR (2010) Produção de etanol. Faculdade de Ciência e Tecnologia de Montes Claros- FACIT. Montes Claros. Minas Gerais. Disponível em: http://www.ebah.com.br/content/ ABAAABRQsAJ/producao-etanol. Accessed 20 de jan 2015.

46. Regassa TH, Wortmann CS (2014) Sweet sorghum as a bioenergy crop: literature review. Biomass Bioenergy 64:348-355. https:// doi.org/10.1016/j.biombioe.2014.03.052

47. Carvalho NHC (2010) Análise da viabilidade econômica de um modelo de produção de energia e alimentos, GERIPA, em comparação com a produção tradicional de etanol no Brasil. Universidade de São Paulo, São Paulo

48. Schutz F (2013) Produção de etanol em pequena escala: um estudo da viabilidade econômica a partir das experiências de Cândido Godói e de ljuí (RS) para o ano de 2012

49. UNICA (2015) Cana-de-Açúcar. Disponível em: https://unica .com.br/. Accessed 2 de jul 2015

50. Chiara M (2013) Preço da terra agrícola subiu $227 \%$ em dez anos, quase o dobro da inflação. J Est São Paulo 4:B1

51. NOVACANA (2013) Como é feito o processamento da cana-deaçúcar nas usinas. disponivel em http://www.novacana.com/ usina/como-e-feito-processamento-cana-de-açúcar. Accessed 4 Jul. 2014

52. Smith J, Van Ness H, Abbott $M$ (2007) Introdução à termodinâmica da engenharia química, 7 th edn. LTC, Rio de Janeiro, $p$ 200

53. Hugot $E$ (1977) Manual da engenharia açucareira, vol 2. Mestre Jou, São Paulo

54. Martinho S (2013) Treinamento Básico da Produção Industrial - USM

55. Mathur S, Umakanth AV, Tonapi VA, Sharma R, Sharma MK (2017) Sweet sorghum as biofuel feedstock: recent advances and available resources. Biotechnol Biofuels 10(1):146. https:// doi.org/10.1186/s13068-017-0834-9

56. Appiah-Nkansah NB, Li J, Rooney W, Wang D (2019) A review of sweet sorghum as a viable renewable bioenergy crop and its techno-economic analysis. Renew Energy 143:1121-1132. https ://doi.org/10.1016/j.renene.2019.05.066

57. Bioenergia CJD (2015) Sorgo Sacarino e a produção de etanol. Disponível em http://www.canalbioenergia.com.br/sorgo-sacar ino-e-uma-boa-alternativa-na-producao-de-etanol/. Accessed 06 de jul 2015

58. Riahi K, Roelirl RA (2000) Greenhouse gas emissions in a dynamicsas-usual scenario of economic and energy development. Technol Forecast Soc Change 63(2-3):175-205

59. Nakicenovic N, Alcamo J, Davis G, de Vries B, Fenhann J, Gaffin S, Gregory K, Griibler A, Jung TY, Kram T, La Rovere EL, Michaelis L, Mori S, Morita T, Pepper W, Pitcher H, Price L, Riahi K, Roehrl A, Rogner H-H, Sankovski A, Schlesinger M, Shukla P, Smith S, Swart R, van Rooijen S, Victor N, Dadi Z, Special Report on Emissions Scenaries (2018) A especial report of working group III of the intergovernamental panel on climate change. Cambridge University Press, Cambridge, p 608

60. IEA (1995) (International Energy Agency), 1995 World Energy Outlook, 1995 Edition I IEA/OECD, Paris

61. Fernandes PG, André M, Coelho FC, Abreu MC, Bertolino KM (2014) Influência do espaçamento e da população de plantas de sorgo sacarino em diferentes épocas semeadura. Cienc Rural 44(6):975-981. https://doi.org/10.1590/S0103-8478201400 0600004
62. Briand CH, Geleta SB, Kratochvil RJ (2018) Sweet sorghum (Sorghum bicolor [L.] Moench) a potential biofuel feedstock: analysis of cultivar performance in the Mid-Atlantic. Renew Energy 129:328-333. https://doi.org/10.1016/j.renene.2018.06.004

63. Linton JA, Miller JC, Little RD, Petrolia DR, Coble KH (2011) Economic feasibility of producing sweet sorghum as an ethanol feedstock in the southeastern United States. Biomass Bioenergy 35(7):3050-3057

64. Billings $M$ (2015) Biomass sorghum and sweet sorghum data gathering report. In: W\&A Crop Insurance. USDA-RMA, CTOR: Jaime Padget, Missouri Watts and Associates, Inc.

65. Kim M, Day DF (2010) Composition of sugar cane, energy cane, and sweet sorghum suitable for ethanol production at Louisiana sugar mills. J Ind Microbiol Biotechnol 38(7):803-807. https:// doi.org/10.1007/s10295-010-0812-8

66. Blank DMP (2015) The context of climate changes and its victims. Mercator, Fortaleza 14(2):157-172. https://doi.org/10.4215/ RM2015.1402.0010

67. Bordonal RO, Carvalho JLN, Lal R, Figueiredo EB, Oliveira BG, La Scala N Jr (2018) Sustainability of sugar cane production in Brazil. A review. Agron Sustentar Dev 38:13. https://doi. org/10.1007/s13593-018-0490-x

68. García CA, Fuentes A, Hennecke A, Riegelhaupt E, Manzini F, Masera O (2011) Emissões de gases de efeito estufa no ciclo de vida e balanços energéticos da produção de cana-de-açúcar no México. Appl Energy 88:2088-2097. https://doi.org/10.1016/j. apenergy.2010.12.072

69. Ottman MJ, Kimball BA, Pinter PJ, Wall GW, Vanderlip RL, Leavitt SW, LaMorte RL, Matthias AD, Brooks TJ (2001) Elevated $\mathrm{CO}_{2}$ increases sorghum biomass under drought conditions. New Phytol 150:261-273

70. Grossi MC, Justino F, Andrade CLT, Santos EA, Rodrigues RA, Costa LC (2013) Modeling the impact of global warming on the sorghum sowing window in distinct climates in Brazil. Eur J Agron 51:53-64

71. Kelland ME, Wade PW, Lewis AL, Taylor LL, Sarkar B, Andrews MG, Beerling DJ (2020) Increased yield and $\mathrm{CO}_{2}$ sequestration potential with the $\mathrm{C}_{4}$ cereal Sorghum bicolor cultivated in basaltic rock dust-amended agricultural soil. Glob Chang Biol 26(6):3658-3676. https://doi.org/10.1111/gcb.15089

72. Barcelos CA, Maeda RN, Santa Anna LMM, Pereira N Jr (2016) Sweet sorghum as a whole-crop feedstock for ethanol production. Biomass Bioenergy 94:46-56

73. Mussatto SI, Dragone G, Guimarães PM, Silva JPA, Carneiro LM, Roberto IC et al (2010) Technological trends, global market, and challenges of bio-ethanol production. Biotechnol Adv 28(6):817-830

74. Barcelos C, Maeda R, Betancur G, Pereira N Jr (2011) Ethanol production from sorghum grains [Sorghum bicolor (L.) Moench]: evaluation of the enzymatic hydrolysis and the hydrolysate fermentability. Braz J Chem Eng 28(4):597-604

75. Camargo H (2011) Sorgo sacarino é alternativa para a produção de etanol. Disponível em: http://revistagloborural.globo.com/ Revista/Common/0,EMI231692-18281,00-87SORGO+SACAR INO+E+ALTERNATIVA+PARA+A+PRODUCAO+DE+ETANOL.html. Accessed 22 de jan. 2015

76. Oliveira M (2012) Opção produtiva: Sorgo é plantado para produzir etanol na entressafra de cana. Rev Pesq FAPESP-Edição 193:62-65

77. Santos RF, Placido HF, Garcia EB, Cantu C, Albrecht AJP, Albrecht $L P$ et al (2015) Sorgo sacarino na produção de agroenergia. Rev Bras Energias Renov 4:1-12

Publisher's Note Springer Nature remains neutral with regard to jurisdictional claims in published maps and institutional affiliations. 